\title{
PENERAPAN VALUE DISCIPLINE STRATEGY PADA BANK KALTIM CABANG TANA PASER
}

\author{
Wahyuni ${ }^{1),}$ Jajang Nurjaman ${ }^{2)}$ \\ ${ }^{1,2}$ Teknik Informatika, Fakultas Pascasarjana Teknik Informatika, Universitas AMIKOM \\ 1,2 Jl. Ring Road Utara, Condongcatur, Yogyakarta, 55281 \\ E-mail : unniecandoit@gmail.com ${ }^{1)}$, za2ng2509@gmail.com ${ }^{2)}$
}

\begin{abstract}
ABSTRAK
Bank Daerah saat ini diharapkan mampu bersaing dengan bank-bank swasta dalam meningkatkan kualitas taraf hidup masyarakat, selain untuk dapat menghimpun dana masyarakat di daerah tersebut. Bank Kaltim Cabang Tana Paser yang merupakan bank daerah di Kabupaten Tana Paser terus berupaya untuk memberikan layanan terbaik kepada nasabahnya dalam bentuk pelayanan produk dan jasa. Sesuai dengan visinya "Menjadi The True Regional Champion yang Kuat, Kompetitif dan Kontributif dalam mendukung pertumbuhan ekonomi daerah yang berkualitas", Bank Kaltim Cabang Tana Paser membutuhkan suatu strategi bisnis untuk mencapai visi tersebut yaitu dengan menggunakan Value Discipline Strategy. Value discipline strategy atau bisa disebut disiplin nilai pertama kali dikemukakan oleh seorang presiden dari perusahaan Treacy yaitu Michael Treacy dan Fred Wierseam. Pada dasarnya, teori ini menekankan pentingnya identifikasi terhadap segmen pasar (market segment). Menurut pandangan ini, ada tiga segmen generik, diantaranya adalah Operational Excellence,Product Leadership,Customer Intimacy. Untuk dapat menentukan jenis strategi yang tepat, maka dibutuhkan suatu analisis baik dari faktor eksternal dan internal. Setelah dilakukan analisis dapat disimpulkan bahwa jenis strategi yang tepat untuk diterapkan adalah Customer Intimacy dimana pada jenis strategi ini Bank Kaltim Cabang Tana Paser difokuskan pada pendekatan terhadap nasabah.
\end{abstract}

Kata Kunci: Value Disciplines, Operational Excellence,Product Leadership,Customer Intimacy, Bank.

\section{PENDAhUluAN}

Bank Kaltim adalah salah satu Perusahaan Daerah (BUMD) milik Pemerintah Provinsi dan Pemerintah Kabupaten/Kota se Kalimantan Timur. Keberadaan Bank Kaltim mempunyai maksud dan tujuan untuk membantu dan mendorong pertumbuhan perekonomian \& pembangunan daerah di segala bidang serta sebagai salah satu sumber pendapatan asli daerah dalam rangka meningkatkan taraf hidup rakyat sehingga terwujudnya masyarakat Kalimantan Timur yang sejahtera. Bank Kaltim berpusat di Samarinda dan memiliki 15 kantor cabang yang tersebar di beberapa kabupaten/kota di Kalimantan Timur dan di Jakarta, dan salah satu dari kantor cabang tersebut adalah Bank Kaltim Cabang Tana Paser.

Sebagai penghimpun, penyalur dan pelayan jasa dalam lalu lintas pembayaran dan peredaran uang di masyarakat, saat ini Bank Kaltim Cabang Tana Paser dituntut untuk menjadi salah satu titik penting dalam menunjang kemajuan daerah Tana Paser. Untuk menapai hal tersebut, Bank Kaltim Cabang Tana Paser harus selalu meningkatkan performa baik itu secara internal maupun eksternal. Namun dalam proses meningkatkan performa, tentulah bank tersebut harus memiliki strategi bisnis yang terencana, efektif dan efisien guna mencapai tujuan yang diharapakan. Ditambah dengan persaingan dari bank lain yang saat ini semakin banyak dengan memasarkan keunggulan produk dan jasanya, maka tentu Bank Kaltim Cabang Tana Paser harus memiliki strategi bisnis yang tujuan akhirnya untuk meyakinkan masyarakat khususnya masyarakat Kabupaten Tana Paser agar dapat menyimpan dananya di bank tersebut. Terlebih untuk bank daerah yang dituntut untuk memberikan pelayanan prima dibandingkan para pesaing yang merupakan bank swasta. Agar tujuan untuk membangun dan mengembangkan potensi daerah yang bersangkutan dapat direalisasikan secara maksimal dan optimal.

Untuk dapat bersaing dan berkompetisi melawan kompetitornya dalam kasus ini adalah bank-bank lain, maka dibutuhkan suatu analisa dan strategi bisnis. Strategi yang digunakan adalah strategi yang dikemukakan oleh Treacy dan Wiersma yaitu "Three Part to Market Leadership" atau bisa dikatakan value discipline yang terdiri dari tiga jenis, yaitu: operational excellence, customer intimacy, dan product leadership. Melalui strategi ini kita bisa mengetahui jenis strategi apa yang tepat yang bisa diterapkan pada Bank Kaltim Cabang Tana Paser. 


\section{RUANG LINGKUP PENELITIAN}

Permasalahan difokuskan pada penerapan value discipline strategy pada Bank Kaltim Cabang Tana Paser untuk memutuskan jenis strategi apa yang tept untuk diterapkan. Adapun jenis strategi tersebut meliputi :

1. Operational Excellence

2. Product leadership

3. Costumer Intimacy

\section{BAHAN DAN METODE}

Adapun bahan penelitian yang digunakan adlah sebagai berikut:

\subsection{Value Discipline Strategy}

Value discipline strategy atau bisa disebut disiplin nilai pertama kali dikemukakan oleh seorang presiden dari perusahaan Treacy yaitu Michael Treacy dan Fred Wierseam, seorang wakil presiden dari CSC Index yaitu sebuah perusahaan konsultan manajemen internasional.

Menurut Treacy \& Wiersma dalam Vliet (2013), pada dasarnya teori ini menekankan pentingnya identifikasi terhadap segmen pasar (market segment). Menurut pandangan ini, ada tiga segmen generik, atau dengan kata lain ada tiga jenis value discipline strategy yaitu:

\subsubsection{Operational Excellence}

Operational Excellence dijelaskan sebagai strategi spesifik yang pendekatannya pada produksi dan penyampaian suatu produk dan jasa. Tujuan dari perusahaan yang mengadopsi strategi ini adalah untuk menjadi pemimpin pasar dalam hal pharga dan kenyamanan. Perusahaan tidak kenal lelah untuk mencari cara bagaimana dapat meminimalisir kelebihan biaya, menghilangkan langkah lanjutan pada produksi, mengurangi transaksi, dan mengoptimasi proses bisnis. Perusahaan fokus pada memberikan produk dan jasanya dengan harga yang kompetitif tetapi dengan kualitas yang baik.

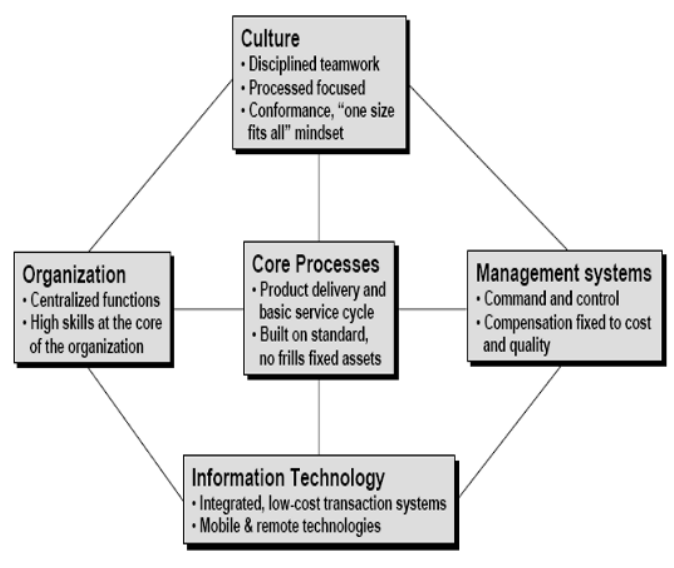

Gambar 1. Operating Model of Operational

\subsubsection{Product Leadership}

Perusahaan yang menggunakan strategi ini berusaha untuk menciptakan produk dan jasa yang inovatif. Pertama, mereka harus kreatif. Dikatakan kreatif karena mereka harus mencari ide-ide di luar dari kebiasaan yang sudah diterapkan diperusahaan tersebut. Kedua, mereka harus secara cepat memasarkan ide-ide tersebut ketiga, perusahaan harus terus menerus berinovasi.

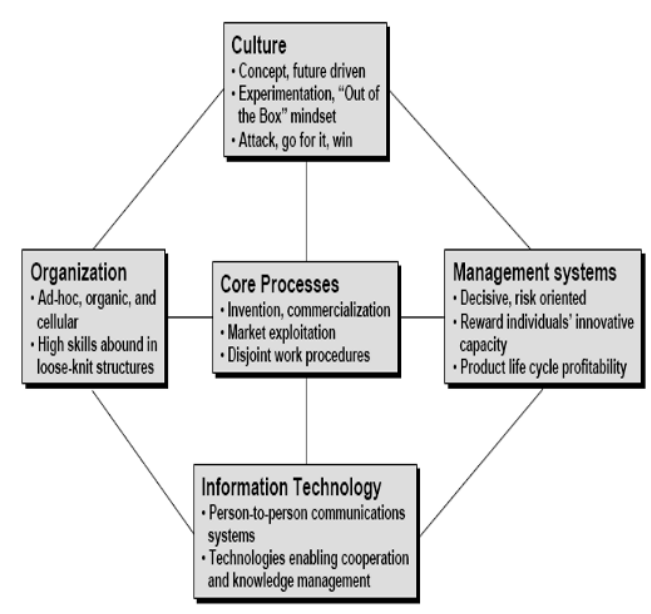

Gambar 2. Operating Model of Product Leadership

\subsubsection{Customer Intimacy}

Pendekatan customer intimacy adalah pada pembuatan produk atau jasa yang dapat meningkatkan kepercayaan pelanggan. Harga produk dan jasa dari perusahaan yang mengadopsi strategi ini bisa saja mahal, namun dapat membangun kepercayaan pelanggan dalam waktu yang sangat lama bahkan seumur hidup. Oleh karena itu pegawai pada perusahaan ini akan melakukan apa saja tanpa mengharapkan penghargaan lebih untuk dapat mengetahui apa yang benar-benar diinginkan oleh pelanggan. Bukan hanya keinginan yang bersifat general, namun keinginan-keinginan yang bersifat lebih spesifik.

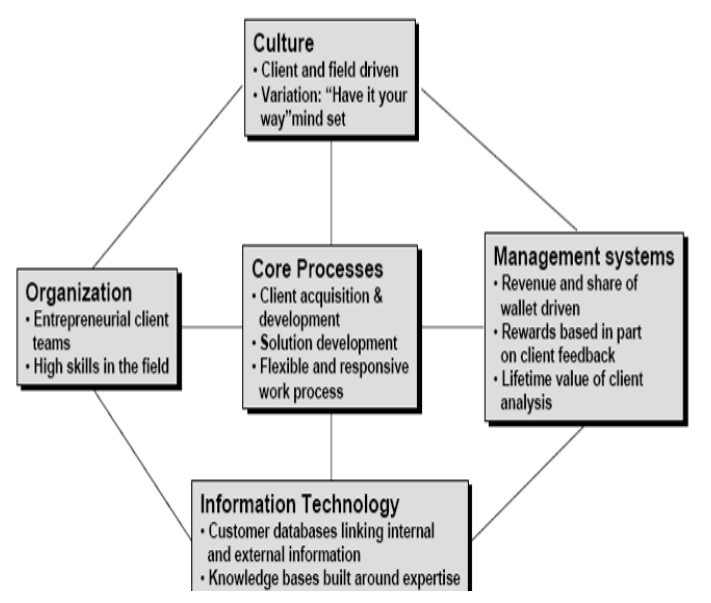

Gambar 3. Operating Model of Customer Intimacy

Perusahaan perlu memfokuskan usahanya untuk mengejar satu disiplin dan menjadi hebat dalam hal itu, 
tetapi sekaligus mempertahankan performa di dua disiplin lain pada ambang batas rata-rata industri.

Untuk dapat menentukan strategi apa yang tepat dari ketiga jenis strategi di atas, maka dibutuhkan analisis mengenai faktor internal dan eksternal yang mempengaruhi penerapan strategi pada perusahaan tersebut. Adapun faktor eksternal meliputi lingkungan ekonomi perusahaan, kebutuhan pasar, dan kompetitor dari perusahaan tersebut. Sedangkan faktor internal meliputi permintaan-permintan stakeholder yang kuat, sumber daya, dan kompetensi dari perusahaan tersebut. Kita dapat melihat bentuk umum dari value discipline seperti pada gambar 4.



Figure 2.9 Forces that shape strategy

\section{Gambar 4. Bentuk Umum Strategi Bisnis}

\section{METODE ANALISIS}

Untuk dapat menganalisis faktor-faktor yang mempengaruhi dalam penerapan suatu jenis strategi, baik faktor eksternal maupun internal, maka dilakukanlah tahapan wawancara kepada salah satu pegawai Bank Kaltim Cabang Tana Paser. Setelah mengajukan beberapa pertanyaan terkait faktor-faktor eksternal dan internal tersebut, dilakukanlah analisis terhadap jenis strategi yang tepat untuk diterapkan berdasarkan jawaban-jawaban yang diberikan.

\section{PEMBAHASAN}

Untuk menganalisis faktor-faktor yang mempengaruhi penerapan value discipline strategy baik faktor eksternal maupun internal, penulis sudah melakukan tahapan wawancara kepada salah satu pegawai dari bank tersebut. Setelah melakukan wawancara, penulis mencoba menganalisis faktor-faktor tersebut berdasarkan dari jawaban yang diberikan.

\subsection{Analisis Faktor Eksternal}

Dari gambar bisnis strategi di atas faktor-faktor eksternal yang mempengaruhi penerapan value discipline strategy ada tiga, yaitu lingkungan ekonomi, kebutuhan pasar, dan kompetitor.

\subsubsection{Lingkungan Ekonomi}

Dari sisi lingkungan ekonomi penduduk di sekitar Bank Kaltim Cabang Tana Paser. Dari hasil wawancara dikatakan bahwa keadaan lingkungan ekonomi disekitar bank di dominasi oleh pedagang. Selain itu mayoritas penduduknya memiliki pekerjaan sebagai nelayan, pedagang dan pegawai negeri sipil yang bisa dikatakan bahwa penduduk di daerah tersebut termasuk penduduk yang memiliki tingkat ekonomi menengah ke atas. Dari jawaban tersebut dapat disimpulkan bahwa bank kaltim mempunyai peluang besar untuk dapat mengajak dan menawarkan jasa kepada masyarakat di daerah tersebut.

\subsubsection{Kebutuhan Pasar}

Dari sisi kebutuhan pasar, saat ini masyarakat sangat membutuhkan adanya fasilitas peminjaman dana yang dapat diberikan oleh bank, khususnya pinjaman dana yang sesuai dengan jenis pekerjaan mereka misalnya kredit yang disesuaikan dengan bidang perikanan, peternakan, perkebunan dan pertanian sehingga tidak begitu memberatkan masyarakat. Selain kebutuhan pada fasilitas peminjaman dana, saat ini para nasabah Bank Kaltim Cabang Tana Paser juga membutuhkan adanya teknologi yang dapat memberikan kemudahan dalam bertransaksi seperti pengecekkan saldo, pengiriman uang secara elektronik atau bisa disebut transfer yang saat ini masih terbatas pada internal bank itu sendiri atau tidak bisa mentransfer ke bank lain.

\subsubsection{Kompetitor}

Dari sisi kompetitor, tentu Bank Kaltim Cabang Tana Paser memiliki banyak kompetitor khususnya bank-bank swasta yang juga memiliki pasar yang sama dan bersaing dalam hal pelayanan maupun produk.

\subsection{Analisis Faktor Internal}

Ada tiga faktor yang termasuk ke dalam faktor internal yang mempengaruhi penerapan strategi vaue discipline yaitu: permintaan stakeholder, sumber daya dan kompetensi dari perusahaan tersebut.

\subsubsection{Permintaan Stakeholder}

Dari sisi permintaan stakeholder, yang berperan sebagai stakeholder disini adalah Pemerintah Kabupaten Pasir dimana sangat berperan dalam memajukan bank daerah yaitu Bank Kaltim Cabanng Tana Paser. Namun stakeholder pun memiliki beberapa keinginan-keinginan seperti penerimaan pegawai kontrak di masing-masing daerah diutamakan putra daerah, bank selalu berperan aktif dalam kegiatan-kegiatan pemerintah daerah, menjalankan CSR sebagai kontribusi perusahaan terhadap kemajuan daerahnya serta membuka jaringan kantor sampai ke pelosok daerah dengan target di tiap kecamatan yang ada Kabupaten Tana Paser.

\subsubsection{Sumber Daya}

Dari sisi sumber daya, Bank Kaltim memiliki sumber daya yang sangat baik, mumpuni dan mempunyai kemampuan untuk mengembangkan perusahaan. Namun saat ini Bank Kaltim masih menggunakan jasa vendor untuk membangun atau 
mengembangkan sistem sehingga sumber daya yang baik itu dirasa kurang bisa mengeksplore kemampuannya secara optimal.

\subsubsection{Kompetensi}

Sedangkan dari sisi kompetensi, pelayanan dan produk masih dapat bersaing dengan bank-bank lainnya. Misalnya dalam hal layanan kredit yang ditawarkan, dimana suku bunga yang ditawarkan kepada nasabah sangat bersaing dengan perkreditan yang ditawarkan oleh bank-bank swasta lainnya.

\subsection{Strategi Yang Dapat Diterapkan}

Melalui beberapa analisis faktor eksternal dan internal di atas, maka jenis strategi value discipline yang tepat untuk digunakan adalah Customer Intimacy dimana pada strategi jenis ini lebih mengarahkan kepada hubungan yang mendalam dan jangka panjang antara Bank Kaltim Tana Paser dengan nasabahnya. Kenapa harus memilih customer intimacy? Karena seperti kita ketahui bahwa bank merupakan perusahaan yang menawarkan produk dan jasa yang berhubungan erat dengan nasabahnya. Dimana jasa dari bank itulah yang menjadi modal utama untuk menarik pelanggan walaupun tidak dipungkiri bank tersebut juga mempunyai produk-produk yang bisa ditawarkan. Untuk mencapai hal ini Bank Kaltim Cabang Tana Paser harus membangun komunikasi yang baik kepada nasabah.

Berdasarkan model dari operasi customer intimacy ada lima fitur utama yang akan dijabarkan yaitu proses inti, organisasi, sistem manajemen, budaya dan teknologi informasi.

\subsubsection{Proses Inti}

Dalam prosesnya, bank ini harus bisa memberikan solusi kepada nasabah mengenai apa yang dibutuhkan oleh nasabah tersebut. Kita bisa mengambil contoh analisa kebutuhan pasar dimana nasabah membutuhkan suatu fasilitas kredit yang dapat dijangkau oleh masyarakat itu sendiri misal sesuai dengan pekerjaan mereka. Maka Bank Kaltim Cabang Tana Paser bisa memberikan solusi terbaik untuk masalah itu seperti memberikan kredit sesuai dengan tingkat kemampuan masyarakat daerah itu. Selain itu berdasarkan kebutuhan pasar, masyrakat membutuhkan bantuan teknologi yang dapat memberikan kemudahan dalam bertransaksi. Maka bank ini harus memikirkan solusi yang terbaik dengan cara membuat suatu aplikasi yang bisa mempermudah masyarakat untuk melakukan transaksi baik transaksi ke dalam bank itu sendiri atau ke bank-bank lainnya. Selain solusi, bank ini juga harus memastikan bahwa solusi yang ditawarkan memang berkerja dengan baik sehingga dapat mencapai tingkat kepuasan konsumen yang tinggi. Selain itu bank ini juga harus memastikan bahwa memiliki hubungan yang baik kepada nasabah dalam jangka waktu panjang. Walaupun tetap harus memiliki SOP (Standart Operating Procedure), namun diharapkan untuk tidak terlalu kaku dan lebih fleksibel dengan tujuan untuk mencapai kepuasan nasabah.

\subsubsection{Organisasi}

Dalam organisasinya, Bank Kaltim Cabang Tana Paser harus membuat keputusan terhadap pegawai yang bisa berinteraksi dengan baik kepada nasabah. Harus bisa menunjukkan keramahan, memiliki pemahaman produk yang baik dan dapat menggali kebutuhan setiap nasabah sehingga nasabah merasa nyaman. Berdasarkan dari analisis faktor internal khususnya sumber daya manusia pada bank ini, dimana sumber daya nya mampu bersaing, sukup mumpuni dan mempunyai kemampuan untuk mengembangkan perusahaan, maka para pemimpin dapat memilih pegawai-pegawai yang tepat untuk menjalankan tugasnya turun ke lapangan secara langsung menemui para nasabah guna mencari tahu apa yang diinginkan nasabah secara spesifik.

\subsubsection{Manajemen Sistem}

Untuk manajemen sistem, sistem yang sudah ada dan matang masih dapat dikembangkan guna mendapatkan hasil yang terbaik. Selain itu adanya penghargaan kepada para pegawai atas tercapainya kepuasan nasabah berdasarkan feedback yang diberikan oleh nasabah tersebut. Adanya sistem yang baik terhadap analisis nasabah yang berlangsung lama bahkan seumur hidup pun juga diperlukan.

\subsubsection{Budaya}

Dalam sisi budaya, Bank Kaltim Cabang Tana Paser harus lebih merangkul solusi yang lebih spesifik dibandingkan solusi yang bersifat general. Harus dapat berkembang dengan pesat dan membangun hubungan yang panjang dengan para nasabah.

\subsubsection{Teknologi Informasi}

Untuk teknologi informasi, diharapkan memiliki database dan aplikasi menyangkut nasabah yang sudah terhubung baik secara internal maupun eksternal terhadap informasi. Misalnya aplikasi nasabah yang merekam semua data nasabah secara lengkap mengenai data inti sampai dengan data permintan-permintaan nasabah sehingga mudah dalam memberikan solusi kepada nasabah atas suatu permintaan. Dan dapat lebih memanfaatkan sumber daya yang ada untuk membangun sebuah sistem perbankan.

\section{KESIMPULAN}

Bank Kaltim Cabang Tana Paser merupakan perusahaan yang bergerak dalam bidang pelayanan dan jasa tentunya selalu berhubungan dengan para pelanggan dalam hal ini adalah para nasabahnya. Berdasarkan visi dari Bank Kaltim tersebut, yaitu "Menjadi The True Regional Champion yang Kuat, Kompetitif dan Kontributif dalam mendukung pertumbuhan ekonomi daerah yang berkualitas", Bank Kaltim Cabang Tana Paser membutuhkan suatu strategi bisnis untuk mencapai visi tersebut yaitu dengan menggunakan Value Discipline Strategy. Value Discipline Strategy memiliki tiga jenis strategi umum yaitu operational exellence, product leadership dan customer intimacy. Untuk dapat memutuskan strategi apa yang tepat untuk diterapkan, maka dilakukanlah suatu analisis baik dari faktor eksternal maupun internal. Faktor eksternal meliputi lingkungan ekonomi, kebutuhan pasar dan kompetitor. Sedangkan faktor internal meliputi permintaanpermintaan stakeholder, sumber daya dan kompetensi bank tersebut. Setelah dilakukan analisis maka dapat diputuskan bahwa jenis strategi yang tepat untuk 
diterapkan adalah "Customer Intimacy" yang mengutamakan kemyamanan kepada nasabahnya. Meningkatkan kepercayaan nasabah terhadap Bank Kaltim Cabang Tana Paser dengan cara berusaha menari tahu kebutuhan-kebutuhan nasabah secara spesifik kemudian memberikan solusi dan menerapkannya. Sehingga terciptalah hubungan yang erat antara nasabah dan Bank Kaltim Cabang Tana Paser. Dan timbul lah kepercayaan yang berlangsung seumur hidup.

\section{SARAN}

Berdasarkan hasil analisis penerapan strategi yang tepat untuk digunakan pada Bank Kaltim Cabang Tana Paser, maka penulis ingin menyampaikan beberapa saran sebagai berikut:

1. Untuk penelitian selanjutnya diharapkan dapat memberikan analisis yang lebih luas terhadap faktorfaktor eksternal dan internal yang mempengaruhi penerapan strategi Value Discipline di Bank Kaltim Cabang Tana Paser.

2. Diharapkan dapat memberikan analisis mengenai jenis strategi baru yang dapat di terapkan di Bank Kaltim Cabang Tana Paser selain menggunakan strategi Value Discipline seperti framework strategy, dan lain-lain.

3. Selain membahas mengenai pelayanan jasa di Bank Kaltim Cabang Tana Paser sehingga didapatkanlah jenis strategi customer intimacy untuk dapat diterapkan, diharapkan untuk penelitian selanjutnya dapat membahas mengenai produk-produk yang ditawarkan sehingga bisa menggunakan jenis strategi lain dari value discipline seperti operational excellence bahkan bisa jadi dapat menerapkan jenis strategi product leadership.

\section{DAFTAR PUSTAKA}

Kurniawan, Djoko. 2014. Customer Intimacy. http://www.djokokurniawan.com/kepuasanpelanggan/customer-intimacy. (diakses tanggal 2 Juni 2017).

Nugrahani, T., 2012, Penerapan value Disciplines Dalam Mempertahankan Market Leader BRI. Tesis. Universitas Gajah Mada Yogyakarta.

Saputro, Rahadian A., 2010, Pengujian strategi value disciplines pada PT Pagilaran. Tesis. Universitas Gajah Mada Yogyakarta.

Setiawan, D., 2015. Strategi PT. Pertaga Untuk Menjadi Pemimpin Pasar Industri Gas Nasional. Tesis. Universitas Gajah Mada Yogyakarta.

Treacy, M. \& Wiersma, F., 2007, The Discipline of Market Leaders: Choose Your Customers, Narrow Your Focus, Dominate Your Market, Hachetee UK.

Vliet, van Vincent. 2013. Value Disciplines. https://www.toolshero.com/strategy/valuedisciplines-treacy-wiersema. (diakses tanggal 2 Juni 2017).

Ward. J. \& Peppard, J., 2016, The Strategic Management of Information Systems:Building a Digital Strategy, John Willey \& Sons. 